\title{
JPAK
}

Jurnal Pendidikan Akuntansi \& Keuangan

Kajian dampak keputusan keuangan terhadap nilai perusahaan. Studi empiris pada perusahaan manufaktur yang terdaftar di bei periode 2003-2010

(Banter Laksana)

Kajian Pembiayaan Mudharabah Terhadap Pendapatan Operasional Bank Syariah (Studi Kasus Bank BNI Syariah)

(Nurhajati, Dudung Abdulrahman)

Pengaruh Model Pembelajaran Kooperatif Tipe Think Pair Share Terhadap Hasil Belajar Siswa Pada Mata Pelajaran Akuntansi di SMA Laboratorium Percontohan Bandung.

(Muni Anisa, Eka Yulianti)

Pengembangan Media Pembelajaran Akuntansi Keuangan dalam. Meningkatkan Penguasaan Kompetensi Vokasional Mahasiswa Fakultas Pendidikan Ekonomi dan Bisnis.

(Kurjono)

Pengaruh Pembiayaan Bagi Hasil Terhadap Profitabilitas PT. Bank Mega Syariah Periode 2008-2011

(Imas Purnamasari, Widi Asih Noor Latifah)

Pengaruh Kapabilitas Organisasi Terhadap Perencanaan Strategis Dan Dampaknya Terhadap Kinerja Organisasi Dalam Pemungutan Pajak Kendaraan Bermotor Di Propinsi Jawa Barat

(Nugraha)

Pengaruh volume pemberian-kredit terhadap tingkat-pendapatan-bank pada PT.Bank Danamon

(Leni Yuliyanti dan Nita Gantini Gunawan) 


\title{
JPAK \\ JURNAL PENDIDIKAN AKUNTANSI \& KEUANGAN \\ ISSN 2337-408X \\ Volume 01, Nomor 01, JANUARI 2013, hlm. 1-59
}

Terbit dua kali setahun pada bulan Januari dan Juli.

\section{DEWAN REDAKSI}

\author{
KETUA \\ Kurjono \\ ANGGOTA \\ Imas Purnamasari \\ Leni Yuliyanti \\ Asep Kurniawan \\ DEWAN EDITOR \\ Nugraha \\ (Universitas Pendidikan Indonesia) \\ Meta Arief \\ (Universitas Pendidikan Indonesia) \\ DEWAN PAKAR \\ Dede Ruslan \\ (Universitas Negeri Medan) \\ Rina Trisnawati \\ ( Universitas Muhamaddiyah Surakarta) \\ STAFF ADMINISTRASI \\ R. Dian Hardiana \\ Jemmi Angga Ruhyat
}

Alamat Redaksi : JPAK Program Studi Pendidikan Akuntansi

Fakultas Pendidikan Ekonomi dan Bisnis

Universitas Pendidikan Indonesia

Jl. Dr. Setiabudhi No. 229 Bandung

E-mail :Jpak.jurnalpendakuntansiupi@yahoo.com 


\section{JPAK \\ JURNAL PENDIDIKAN AKUNTANSI \& KEUANGAN \\ ISSN 2337-408X \\ Volume 01, Nomor 01, JANUARI 2013, hlm. 1-59}

\section{DAFTAR ISI}

Kajian Dampak Keputusan Keuangan Terhadap Nilai Perusahaan. Studi Empiris Pada Perusahaan Manufaktur Yang Terdaftar Di BEI Periode 2003-2010 (Banter Laksana) .

Kajian Pembiayaan Mudharabah Terhadap Pendapatan Operasional

Bank Syariah (Studi Kasus Bank Bni Syariah). (Nurhajati, Dudung Abdulrahman).

Pengaruh Model Pembelajaran Kooperatif Tipe Think Pair Share Terhadap Hasil Belajar Siswa Pada Mata Pelajaran Akuntansi Di SMA Laboratorium Percontohan Bandung. (Muni Anisa, Eka Yulianti)

Pengembangan Media Pembelajaran Akuntansi Keuangan Dalam Meningkatkan Penguasaan Kompetensi Vokasional Mahasiswa Fakultas Pendidikan Ekonomi Dan Bisnis.(Kurjono)

Pengaruh Pembiayaan Bagi Hasil Terhadap Profitabilitas Pt. Bank Mega Syariah Periode 2008-2011. (Imas Purnamasari, Widi Asih Noor Latifah)..

Pengaruh Kapabilitas Organisasi Terhadap Perencanaan Strategis Dan Dampaknya Terhadap Kinerja Organisasi Dalam Pemungutan Pajak Kendaraan Bermotor Di Propinsi Jawa Barat. (Nugraha)

Pengaruh Volume Pemberian Kredit Terhadap Tingkat Pendapatan Bank Pada Pt. Bank Danamon (Leni Yuliyanti, Nita Gantini Gunawan) 